\title{
Rambu-rambu Penyusunan Skala Sikap Model Likert untuk Mengukur Sikap Siswa
}

\author{
Mawardi \\ mawardi@staff.uksw.edu \\ Pendidikan Guru Sekolah Dasar FKIP Universitas Kristen Satya Wacana
}

The Direction Of The Likert Attitude Scale Formulation To Measure Student's Attitude

\begin{abstract}
The general finding shows that the assessment instrument for attitude domain contained in each of the sub-theme in Buku Guru SD / MI, uses the rubric of student behavior observations, even though theoretically the nature of attitude is not the same as behavior, this shows the problem in the implementation of the Curriculum 2013. Ideally, the attitude domain assessment uses attitude measurement instruments, which include components of cognition, affection, and conation. Cognition is related to beliefs (beliefs, ideas, and concepts). The affection component concerns a person's emotional life, while the conation component is a tendency to behave. The three components of attitude do not stand alone, but interact with one another in a complex way. To overcome this problem, direction needs to be prepared for the correct attitude assessment instrument, especially containing the nature of attitudes and their differences with behavior, how to measure attitudes, and how to arrange the attitude scale of the Likert model. The steps in preparing the Likert model attitude scale include are: 1) compiling the attitude object statement; (2) conducting instrument trials; (3) determiinge the score for each statement (instrument blue-print); (4) analyzing items to determine the reliability and validity of the instrument.
\end{abstract}

Keywords: Likert Scale Attitude Model, Student Attitudes

\section{Article Info}

Received date: 22 September $\quad$ Revised date: 23 September 2019 Accepted date: 24 September 2019 2019

\section{PENDAHULUAN}

Terbitnya buku guru dan buku siswa setelah pemberlakuan Kurikulum 2013 pada jenjang SD/MI tidak lepas dari "niat baik" Kemendikbud dalam merespon "keluhan guru" berkaitan dengan beratnya beban guru SD dalam menyiapkan perangkat administrasi akademik dan penyusunan materi ajar. Niatan tersebut tentu tidak sertamerta menyelesaikan masalah guru. Penyediaan buku siswa dan buku guru oleh pemerintah pusat sebagai buku sumber wajib untuk pembelajaran di sekolah, disinyalir menimbulkan permasalahan yang lain. Utamanya tentang relevansi buku-buku tersebut dengan kaidah desain pembelajaran, karakteristik siswa, kompetensi guru dan kondisi lingkungan masyarakat sekitar.

Wijaya (2014: 3), widyaiswara P4TK Matematika Yogyakarta menyatakan bahwa buku siswa menjabarkan usaha minimal yang harus dilakukan peserta didik untuk mencapai kompetensi yang diharapkan. Pernyataan tersebut bermakna bahwa karena buku tersebut adalah acuan minimal, maka dalam proses belajar, peserta didik dipacu untuk mencari dari sumber belajar lain yang tersedia dan terbentang luas di sekitarnya. Konsekuensinya, para guru dituntut memperkaya dengan kreasi dalam bentuk kegiatan-kegiatan lain yang sesuai dan relevan dengan lingkungan alam dan sosial daerah masing-masing. Maknanya adalah bahwa guru merupakan pengendali utama di dalam proses belajar mengajar di kelas. Di sinilah letak pentingnya guru sebagai pengendali kegiatan belajar mengajar di kelas memastikan kualitas buku tersebut.

Struktur buku guru dan buku siswa memang sudah menggambarkan bagaimana komponenkomponen pembelajaran dirancang. Komponen-komponen tersebut mencakup komponen tujuan pembelajaran, materi pembelajaran, gambaran model/metode pembelajaran, media, dan instrumen evaluasi. Isi Buku Guru meliputi (1) jaringan tema, memberi gambaran kepada guru tentang suatu tema yang melingkupi beberapa Kompetensi Dasar; (2) kegiatan pembelajaran tematik terpadu; (3) 
pengalaman belajar yang bermakna; (3) berbagai teknik penilaian peserta didik; (4) informasi yang menjadi acuan kegiatan remedial dan pengayaan; (6) kegiatan interaksi guru dan orang tua; serta (7) petunjuk pengunaan Buku Siswa. Sedangkan buku siswa terutama berisi aktivitas belajar siswa (Sari, 2017: 35). Penggunaan buku guru dan buku siswa tersebut, seirama denngan penerapan Kurikulum tahun 2013 pada jenjang SD/MI dilakukan secara bertahap, agar para guru memiliki cukup waktu untuk merancang komponen-komponen pembelajaran secara lebih baik, sesuai rambu-rambu yang ditetapkan Kemendikbud.

Ada sinyalemen bahwa dalam implementasi Kurikulum 2013 tersebut, para guru kurang kritis terhadap buku guru dan buku siswa yang digunakan. Seandainya buku guru dan buku siswa tersebut kurang baik atau kurang sesuai dengan rambu-rambu pengembangan kurikulum, padahal digunakan sebagai acuan oleh guru dalam penyusunan rancangan pembelajaran, maka kualitas rancangan pembelajaran yang disusun oleh guru kurang baik pula. Seperti telah kita ketahui bahwa penyusunan RPP (Rencana Pelaksanaan Pembelajaran) yang dilakukan oleh guru mengacu pada buku guru dan buku siswa tersebut. Hal ini disebabkan oleh kesibukan guru dalam mengajar, sehingga kurang memiliki perhatian untuk menganalisis buku guru dan buku siswa tersebut (Mawardi, M., Wardani, N. S., Hardini, A. T. A., \& Kristin, F, 2019: 49). Sinyalemen tersebut ternyata ada kebenarannya, paling tidak berdasarkan temuan penelitian Dhinata (2016: viii) yang menyatakan bahwa berdasarkan hasil wawancara dengan guru dan kepala sekolah SD Negeri Mintaragen 7 Kota Tegal, diperoleh informasi bahwa analisis Buku Guru dan Buku Siswa belum pernah dilakukan. Fenomena ini direspon oleh Sari dengan memberikan saran-saran sebaiknya guru melakukan kegiatan analisis terlebih dahulu terhadap Buku Guru dan Buku Siswa yang akan digunakan dalam pembelajaran (Sari, 2017: 132).

Khusus berkaitan dengan komponen penilaian, hasil analisis peneliti sebagai pengampu matakuliah asesmen pembelajaran SD terhadap Buku Guru menemukan bawa secara umum instrumen penilaian ranah sikap belum sesuai dengan kaidah penyusunan instrumen penilaian ranah afektif. Instrumen penilaian yang digunakan hampir di semua sub tema menggunakan rubrik penilaian hasil observasi perilaku siswa, padahal secara teoretik hakikat sikap tidak sama dengan perilaku. Dalam kurikulum 2013 (lihat KI 1 dan KI 2) mengandung muatan sikap, yakni sikap yang berkaitan dengan nilai-nilai budaya bangsa Indonesia yang terkristal dalam Pancasila. Aksentuasi muatan pendidikan yang mengandung muatan sikap tersebut membawa konsekuensi bahwa pengukuran hasil belajar dengan hanya menggunakan tes tidaklah memadai. Oleh karenanya agar gambaran kita tentang hasil belajar yang dicapai oleh siswa menjadi lebih utuh, maka disamping mengukur kemampuan kognitifnya, perlu menyiapkan instrumen pengukuran sikap. Agar memperoleh gambaran yang lengkap tentang bagaimana seharusnya menyusun instrumen penilaian ranah afektif, teutama sikap siswa, berikut dipaparkan hakikat sikap, pengukuan sikap dan skala sikap model Likert.

\section{RAMBU-RAMBU PENYUSUNAN SKALA SIKAP MODEL LIKERT}

\section{Hakikat Sikap}

Mengenai pengertian sikap, banyak ahli dalam bidang psikologi sosial dan sosiologi yang telah memberikan definisi. Akan tetapi ada kesamaan yang dapat diterima semua pihak. Azwar (2011: 3) menjelaskan bahwa sikap diartikan sebagai suatu reaksi atau respon yang muncul dari seseorang individu terhadap objek yang kemudian memunculkan kecenderungan perilaku individu terhadap objek tersebut dengan cara-cara tertentu. Sementara Alport menekankan bahwa sikap merupakan suatu keadaan neuropsikis dari kesiapan seseorang untuk melakukan kegiatan mental dan kesiapan untuk merespon, suatu keadaan batin individu yang terarah pada suatu nilai (Zakaria, 2011: 22). Dari dua pengertian sikap yang telah dikemukakan di atas, Nampak bahwa sikap belum merupakan suatu tindakan atau aktifitas, akan tetapi berupa kesiapan dan kecenderungan untuk merespon. Dengan demikian sikap seseorang tidak dapat diamati secara langsung, melainkan harus ditafsirkan terlebih dahulu dari tingkah laku yang tampak baik verbal maupun non verbal.

Di dalam sikap terdapat tiga komponen yang disebut dengan istilah kognisi, afeksi dan konasi (Mar'at, 2006: 13). Komponen kognisi berhubungan dengan keyakinan (belief, ide dan konsep). Komponen afeksi menyangkut kehidupan emosional seseorang sedangkan komponen konasi merupakan kecenderungan untuk berperilaku. Ketiga komponen sikap tersebut tidak berdiri sendiri, melainkan berinteraksi satu dengan yang lainnya secara kompleks. Dengan demikian timbulnya sikap terhadap suatu objek tidak bisa dilepaskan dari komponen kognisi, afeksi dan konasi. Komponen 
kognisi akan menimbulkan persepsi, ide dan konsep mengenai sesuatu yang dilihat. Persepsi dipengaruhi oleh faktor pengalaman, proses belajar (sosialisasi), keluasan pandangan dan pengetahuan seseorang. Pernyataan ini sejalan dengan Kusaeri, K., \& Cahyan, E. D. H. (2016: 115) yang menyatakan bahwa persepsi merupakan faktor pembentuk sikap. Faktor pengalaman dan proses belajar akan memberikan bentuk dan struktur terhadap hal yang dilihat. Sedangkan keluasan pandangan (cakrawala) dan pengetahuan akan memberi arti kepada obyek yang dimaksud. Kemudian berdasarkan normanorma dan nilai-nilai yang dianut seseorang, maka ia akan mempunyai keyakinan (belief) tertentu terhadap suatu obyek. Selanjutnya komponen afeksi memberikan evaluasi emosional yang berupa perasaan senang atau tidak senang, setuju atau tidak setuju terhadap obyek tersebut. Pada tahab berikutnya berperan komponen konasi yang menentukan kesediaan atau kesiapan untuk bertindak terhadap obyek itu. Secara visual hubungan antara ketiga komponen sikap tadi dapat dilukiskan seperti terlihat dalam gambar 1. Dalam gambar itu terangkum suatu pengertian bahwa persepsi individu terhadap objek tertentu, dan penilaiannya terhadap obyek tersebut akan menentukan sikapnya terhadap obyek itu, bisa positif atau negatif, senang atau tidak senang.

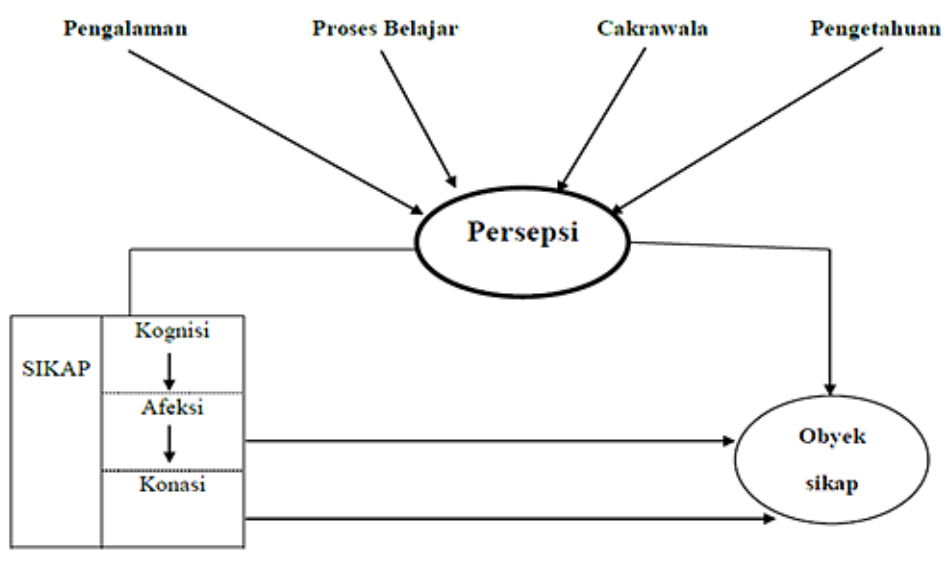

Gambar 1. Hubungan antar komponen sikap

Sikap yang dimiliki oleh seseorang lebih dipandang sebagai hasil belajar dari pada hasil perkembangan atau sesuatu yang diturunkan. Ini berarti bahwa sikap diperoleh melalui interaksi dengan obyek sosial atau peristiwa sosial. Oleh karenanya sikap dapat berubah-ubah, sehingga dapat dipelajari dan dibentuk.

\section{Pengukuran Sikap}

Kusaeri (2019: 63-64) menyatakan bahwa penilaian sikap merupakan kegiatan yang bersifat kompleks, karena berkaitan dengan nilai-nilai yang sulit untuk diukur. Hasil penilaian sikap harus dipahami sebagai proses bukan sebagai hasil proses pembelajaran yang instan dinilai oleh pendidik pada setiap kali menyelesaikan proses pembelajaran. Oleh karenanya, penilaian ini merupakan proses akumulatif terhadap perilaku siswa selama periode waktu tertentu.

Henerson, Moris, dan Fitz Gibbon, mengemukakan ada empat pendekatan yang dapat dipergunakan untuk mengukur sikap seseorang, yaitu: (1) dengan menggunakan laporan diri sendiri (self-report); (2) melalui laporan orang lain, (3) prosedur sosio metri, dan (4) pencatatan dokumen. (Henerson, Moris, dan Gibbon, 1987: 22). Berdasarkan empat pendekatan tersebut kemudian dikembangkan teknik-teknik yang akan digunakan untuk mengukur sikap, seperti: wawancara langsung, laporan tertulis, kuesioner, pengumpulan pendapat (polls), observasi, teknik pilihan sosial, skala sikap, dan masih ada lainnya. Keempat pendekatan dan tekniknya seperti telah disebutkan di atas, masing-masing mempunyai kelebihan dan kekurangan; oleh sebab itu pemilihan terhadap salah satu dari empat pendekatan dan tekniknya tersebut haruslah memperhatikan asumsi yang melandasinya. Misalnya, jika jika kita hendak menggunakan laporan diri sendiri (self-report) dengan teknik skala sikap, maka orang yang sikapnya ingin kita ukur seyogyanya: (1) dapat memahami pertanyaanpertanyaan yang kita ajukan kepadanya; (2) memiliki kesadaran diri yang memadai untuk memberikan informasi yang diperlukan; dan (3) terdapat kemungkinan yang besar bahwa mereka akan menjawab 
pertanyaan secara jujur. Atas dasar prtimbangan tertentu pembahasan kali ini difokuskan pada beberapa hal yang berkenaan dengan skala sikap.

Paling sedikit ada emat model skala sikap yang dikenal orang. Adapun empat skala yang dimaksud ialah : skala Bogardus, skala Thurstone, skala Guttman dan skala Likert. Skala Bogardus umumnya dipergunakan untuk mengukur sikap dari anggota berbagai kelompok yang beragam. Sasaran utamanya ialah ingin mengetahui bagaimana kualitas sikap dari anggota suatu kelompok, misalnya ras, terhadap anggota ras yang lain. Yang dimaksud dengan "kualitas sikap" disini adalah tingkat kepositifan atau kenegatifan sikap individu atau sekelompok orang terhadap anggota diluar kelompoknya. Oleh sebab itu skala Bogardus sering disebut skala jarak sosial (social distance). Pertanyaan-pertanyaan dalam skala Bogardus disusun secara hirarkis, dalam arti pertanyaan terdahulu memiliki intensitas yang lebih rendah dan sekaligus mencakup pertanyaan pertama. Dengan demikian bila penjawab menjawab "ya" pada pernyataan kedua berarti mengiyakan pertanyaan pertama, tidak demikian sebaliknya. Masalah yang dihadapi didalam skala Bogardus antara lain sulitnya menyusun pertanyaan yang berjenjang intensitasnya dalam jumlah besar, apalagi untuk obyek sikap selain dari yang berkenaan dengan jarak sosial.

Skala Thurstone, menurut skala ini, umumnya menerapkan metode perbandingan pasangan (paired comparison) untuk mengukur sikap sieseorang. Namun ternyata prosedur ini tidak cocok jika jumlah item bertambah banyak, sehingga ia kemudian mengembangkan metode interval tampak-setara (equal-appearing interval method). Walaupun kedua metode ini cenderung menghasilkan nilai skala yang mirip, namun Thurstone mencatan lemahnya hubungan antara item dengan skala yang nilai yang terletak diujung kontinum psikologis. Metode interval berurutan (successive interval method) kemudian dikembangkan untuk mengatasi kelemahan tersebut. Sebegitu jauh yang penting popular dan paling banyak digunakan adalah metode interval tampak setara. Dalam praktek skala Thurstone ini jarang dipergunakan mengingat prosedur penyusunannya amat memakan waktu dan tenaga. Di samping itu karena item-itemnya harus dinilai terlebih dahulu oleh suatu "tim ahli", maka skala yang sudah tersusun dapat berubah dan perlu ditinjau kembali dari waktu ke waktu, sebab penilaian para ahli sangat tergantung pada pengetahuan mereka tentang konsep sikap yang hendak diukur.

Skala Guttman, menurut skala Guttman ini suatu variabel biasanya memiliki beberapa dimensi. Misalnya, variabel "nilai anak" bagi suatu keluarga memiliki dimensi ekonomi, dimensi psikologi, dan dimensi sosial. Contoh lain ialah variabel sikap. Seperti yang sudah dikemukakan pada bagian sebelumnya, sikap memiliki dimensi kognisi, afeksi dan konasi. Suatu hal yang hendak dipertahankan oleh Guttman ialah ketunggalan dimensi (unidimensionality). Artinya, skala sebaiknya hanya mengukur satu dimensi saja dari variabel yang memiliki tiga dimensi seperti yang telah disebutkan di atas, menurut Guttman suatu skala nilai anak sebaiknya hanya mengukur salah satu dari dimensi itu. Seperti halnya skala Bogardus, skala Guttman terdiri dari beberapa pertanyaan yang berbobot lebih berat, dia diharapkan akan menyetujui pertanyaan-pertanyaan yang berbobot lebih rendah. Untuk menilai ketunggalan dimensi suatu skala diadakan analisa skalogram mendapatkan koefisien reproduksibilitas dan koefisien skalabilitas. Atas dasar inilah skala Guttman sering disebut sengan metode Skalogram. Dengan analisis skalogram yang relatif rumit itu ternyata jarang diperoleh skala Gutman yang benarbenar unidimensi.

Skala Likert, skala ini, umumnya dimulai dengan penyusunan sejumlah besar pertanyaan sikap (item). Untuk masing-masing item, penyusun perlu menetapkan apakah pernyataan sikap yang disusunnya itu menunjukan dukungan (favourable) atau menolak (unfavourable) terhadap obyek sikap. Akan tetapi dari item-item itu dalam kontinum psikologinya tidak diketahui. Oleh karena didalam memberikan respon, subyek diijinkan memilih salah satu dari kemungkinan jawaban yang disediakan; sangat setuju, setuju, ragu-ragu/ tidak ditentukan (undecided), tidak setuju, sangat tidak setuju. Dengan demikian subyek yang sangat positif sikapnya terhadap suatu obyek akan memiliki jawaban "sangat setuju" untuk pernyataan positif.

\section{Skala Sikap Model Likert}

Skala likert pertama kali dikembangkan oleh Rensis Linkert pada tahun 1932 dalam mengukur sikap masyarakat. Skala ini menggunakan ukuran ordinal sehingga dapat membuat ranking walaupun tidak diketahui berapa kali responden yang satu lebih baik atau lebih buruk dari responden lainnya. Jawaban setiap item insttrumen yang menggunakan skala Likert mempunyai gradasi dari sangat positif sampai sangat negatif, yang dapat berupa kata-kata antara lain: sangat setuju (SS), setuju (ST), raguragu (R), tidak setuju (TS) dan sangat tidak setuju (STS). Urutan setuju atau tidak setuju dapat dibalik 
mulai dari sangat tidak setuju sampai dengan sangat setuju. Langkah-langkah dalam menyusun skala Likert mencakup: (1) menyusun pernyataan obyek sikap; (2) melaksanakan uji coba instrument; (3) menentukan skor untuk masing-masing pernyataan (kisi-kisi instrumen); (4) melakukan analisis item untuk mengetahui keterandalan dan kesahihan instrumen.

\section{Menyusun Item Pernyataan Skala Sikap}

Langkah ke-1, dalam menyusun pernyataan obyek sikap, langkah pertama dimulai dengan menentukan obyek sikap. Obyek sikap orang, benda, peristiwa, lembaga, idea, norma, nilai, budaya, dll. Dalam praktiknya, penentuan obyek sikap ini ditentukan pada saat guru menganalisis KD dalam silabus pembelajaran. Temuan hasil analisis yang dominan ke arah ranah afektif merupakan indikator adanya obyek sikap yang akan dikembangkan menjadi instrumen skala sikap. Contoh obyek sikap: bertanggungjawab terhadap diri sendiri, sesama \& masyarakat, disiplin sekolah, dan lain-lain. Contoh obyek sikap disiplin sekolah ini, yang selanjutnya akan digunakan untuk menjelaskan prosedur penyusunan skala sikap.

Langkah kedua, memberikan batasan dan tujuan yang berkaitan dengan obyek sikap. Misalnya disiplin sekolah diberi batasan berikut: " disiplin sekolah adalah keadaan tertib dimana peraturan sekolah yang berisi seragam sekolah, jam sekolah, cara berperilaku dan etika belajar ditegakkan, agar tidak terjadi perilaku menyimpang, terbiasa hidup tertib dan tercipta kondisi sekolah nyaman untuk belajar". Dalam terminologi penelitian hal ini disebut dengan memberikan definisi operasional penting dilakukan, setidaknya karena dua alasan. Pertama dengan definisi operasional itu kita dapat lebih mudah menentukan indikator dari variabel yang akan diukur. Kedua, pihak lain yang berkepentingan dapat menguji kesahihan konsep kita tentang variabel itu, dan menilai sejauhmana item-item yang disusun sesuai dengan konsep yang telah dirumuskan. Jika pengertian tentang obyek sikap yang menjadi pusat perhatian kita belum jelas, tentu akan menimbulkan kesulitan dalam merumuskan item-item yang dimaksudkan untuk mengukurnya. Dan yang banyak terjadi, kendatipun konsepsi mengenai obyek sikap telah jelas, item-item yang dibuat untuk itu sering tidak relevan

Langkah ketiga, menyusun kisi-kisi komponen/indikator variabel disiplin sekolah. Dengan mengacu pada batasan ini kemudian dicari-cari hal-hal apa sajakah yang ditetapkan dalam sistem peraturan sekolah tersebut. Inilah yang disebut dengan usaha menemukan indikator dari variabel. Misalnya, diperoleh bahwa hal-hal yang diatur dalam disiplin sekolah adalah: (1) maksud dan tujuan disiplin sekolah, (2) manfaat tata tertib, (3) pakaian seragam sekolah (4) terlambat masuk sekolah (5) kebersihan sekolah dan masih banyak lain. Tabel 1 berikut merupakan contoh kisi-kisi penyusunan instrumen skala sikap model Likert.

Tabel 1. Kisi-kisi instrumen skala sikap model Likert

\begin{tabular}{|c|c|c|c|c|c|}
\hline \multirow{2}{*}{$\begin{array}{l}\text { Komponen Indikator } \\
\text { obyek sikap }\end{array}$} & \multicolumn{3}{|c|}{ Komponen sikap } & \multirow{2}{*}{$\mathbf{J m l}$} & \multirow{2}{*}{$(\%)$} \\
\hline & Kognisi & Afeksi & Konasi & & \\
\hline Hakikat disiplin sekolah & 4 & 0 & 0 & 4 & 14 \\
\hline Tujuan disiplin sekolah & 2 & 2 & 1 & 5 & 16 \\
\hline Seragam sekolah & 1 & 2 & 2 & 5 & 16 \\
\hline Jam sekolah & 1 & 2 & 2 & 5 & 16 \\
\hline Cara berperilaku & 1 & 2 & 3 & 6 & 20 \\
\hline Etika belajar & 1 & 2 & 2 & 5 & 16 \\
\hline Total & 10 & 10 & 10 & 30 & 100 \\
\hline
\end{tabular}

Berdasarkan indikator variabel seperti tersebut di atas, barulah ditulis pernyataan-pernyataan yang berkenaan dengan sikap terhadap disiplin sekolah. Dalam rangaka penulisan pernyataan sikap ini, Allen Edward seperti dikutip oleh Azwar memberikan semacam pedoman yang disebutnya sebagai kriteria informal penulisan pernyataan sikap. Kriteria tersebut adalah sebagai berikut: (1) hindari pernyataan yang membicarakan tentang masa lalu; (2) hindari pernyataan yang berupa fakta atau dapat ditafsirkan sebagai fakta; (3) hindari pernyataan yang dapat ditafsir lebih dari satu; (4) hindari 
pernyataan yang tidak relevan dengan obyek psikologis yang hendak diukur; (5) hindari pernyataan yang besar kemungkinannya akan disetujui oleh hampir semua orang yang hampir tidak seorangpun akan menyetujuinya; (6) pilihlah pernyataan-pernyataan yang diyakini akan mencakup keseluruhan rentang skala afektif yang diinginkan; (7) usahakan agar setiap pernyataan ditulis dalam bahasa yang sederhana, jelas dan langsung; (8) setiap pernyataan hendaknya ditulis dengan ringkas, jarang melebihi 20 kata; (9) setiap pernyataan harus berisi hanya satu ide (gagasan) yang lengkap; (10) pernyataan yang berisi unsur universal seperti "semuanya", "selalu", "tak seorangpun", "tidak pernah" dan yang sejenisnya sering menimbulkan penafsiran ganda (ambiguity), dank arena itu harus dihindarkan; (11) hindari penggunaan kata "hanya", "sekedar", dan "semata-mata", terkecuali jika sangat diperlukan; itupun harus sehati-hati mungkin; (12) sedapat mungkin pernyataan dirumuskan dengan kalimat sederhana, bukan kalimat majemuk atau kalimat yang kompleks; (13) hindari pemakaian kata-kata yang kungkin tidak dimengerti oleh mereka yang akan menjawab pernyataan itu; dan (14) hindari pernyataan yang berisi kata negative ganda (Azwar, 2011: 19).

Usahakan dalam menyusun item skala sikap terdiri dari pernyataan positif dan pernyataan negatif yang jumlahnya seimbang atau relatif seimbang. Pernyataan positif merupakan pernyataan yang mendukung atau memihak pada objek sikap, yang dalam contoh pembahasan ini adalah "disiplin sekolah". Contoh pernyataannya: "setiap siswa wajib bertanggung jawab terhadap kelestarian peralatan sekolah". Sebaliknya pernyataan negatif adalah pernyataan yang menolak atau tidak memihak terhadap objek sikap. Misalnya, "peraturan tata tertib sekolah lebih banyak mengekang tingkah laku siswa dari pada menumbuhkan rasa tanggung jawab".

Mengapa pernyataan positif dan negatif harus berjumlah seimbang?. Alasanya, agar responden membaca seluruh pernyataan secara seksama, mengingat semua pernyataan tidak dijawab dengan "setuju" atau "sangat setuju". Dalam kenyataan di lapangan terdapat kecenderungan pada sebagian anggota masyarakat bahwa mereka segan untuk memilih alternatif jawaban "tidak setuju" apalagi "sangat setuju". Secara teknis, apabila responden memilih jawaban "setuju" terhadap pernyataan negatif, itu berarti skor yang diperolehnya akan rendah. Oleh karenanya susunan pernyataan positif dan negatif tidak boleh mengikuti pola tertentu. Penempatannya harus dilakukan secara acak (random).

Ciri khas skala Likert setiap pernyataan umumnya diikuti oleh lima kemungkinan jawaban, yaitu sangat setuju, setuju, ragu-ragu (istilah ragu-ragu dipergunakan sebagai pengganti dari istilah tidak memutuskan (undecided), tidak setuju, dan sangat tidak setuju. Ada sementara orang memilih jawaban untuk menggunakan empat kemungkinan jawaban, dengan menghilangkan jawaban ini dikenal dengan istilah force choice (pilihan paksa). Diberi nama demikian karena responden dipaksa untuk menentukan sikap terhadap suatu obyek, setuju atau tidak setuju. Tidak ada kesempatan baginya untuk menyatakan sikap ragu-ragu atau netral.

Ditinjau dari sudut teori pengukuran (psikometri) model force choice mempunyai kelemahan, karena kontinum psikologis antara jawaban "setuju" dan "tidak setuju" menjadi lebih panjang. Sementara itu dalam praktek agaknya sulit juga menuntut seseorang untuk selalu menunjukan sikap yang jelas-tegas terhadap suatu objek atau suatu titik waktu tertentu. Banyak faktor yang menjadi penyebabnya. Mungkin karena ketidaktahuan atau belum memiliki keterangan yang cukup tentang objek sikap, sehingga individu memiliki penilaian yang ambivalen (seimbang antara penilaian positif dan negatif), atau memungkinkan karena ia tidak dapat memberikan respon yang konsisten terhadap objek sikap yang dihadapkan kepadanya.

Walaupun penafsiran terhadap jawaban "ragu-ragu" masih merupakan salah satu masalah dalam pengukuran sikap, namun hal itu bukan menjadi rintangan untuk tetap mempertahankannya, secara konseptual pencantuman jawaban "ragu-ragu" masih merupakan salah satu masalah dalam pengukuran sikap, namun hal itu bukan menjadi rintangan untuk tetap mempertahankannya. Secara konseptual pencatuman jawaban "ragu-ragu" pada sebagaian besar pernyataan ternyata jarang ditemui. Tentu saja setelah pernyataan-pernyataan sikap itu lulus seleksi dalam proses uji instrumen.

Berkaitan dengan jumlah item, menurut Fernandes seperti dikutip oleh Mar'at (2006: 61), skala Likert paling sedikit terdiri dari 30 item. Ada juga yang berpendapat, 20 item saja sudah cukup. Pendapat manakah yang akan diikuti? Jawaban atas pernyataan ini sangat tergantung pada obyek sikap yang akan diukur. Dalam kesempatan ini cukuplah dikatakan ada hubungan positif antara jumlah item dengan tingkat keterandalan instrumen. Artinya, semakin banyak jumlah item dalam batas tertentu maka koefisien keterandalan instrumen akan semakin besar. Berikut contoh rumusan pernyataan skala sikap dengan obyek sikap disiplin sekolah sesuai dengan kisi-kisi di atas. 
Contoh pernyataan komponen kognisi

1. Disiplin sekolah hakikatnya adalah segala tata tertib yang berkaitan dengan tanggung jawab siswa selaku warga sekolah (+).

2. Disiplin sekolah lebih banyak mengekang perilaku siswa dari pada menumbuhkan rasa tanggung jawab (-).

Contoh pernyataan komponen afeksi

1. Saya mendukung pemberlakuan seragam sekolah agar tidak terjadi persaingan dalam berpakaian $(+)$.

2. Saya kurang mendukung pemberlakuan seragam sekolah karena banyak waktu terbuang hanya untuk menertibkan seragam dari pada dipakai untuk belajar (-).

Contoh pernyataan komponen konasi

1. Seharusnya saya berangkat sekolah lebih awal agar masih cukup waktu untuk mempersiapkan pelajaran (+)

2. Kehadiran saya di sekolah tidak harus lebih awal karena guru yang mengajar tidak mewajibkan hadir lebih awal (-).

Setelah semua pernyataan ditulis, selanjutnya dituangkan dalam format skala sikap seperti contoh berikut:

\section{Petunjuk!}

\section{Skala Sikap tentang Disiplin Sekolah}

Berikut adalah pernyataan yang berkaitan dengan disiplin sekolah. Silakan menyatakan sikap dengan cara memberi tanda centang $(\sqrt{ })$ di bawah kolom STS (Sangat Tidak Setuju), TS (Tidak Setuju), N (Netral), ST(Setuju) dan SS (Sangat Setuju) sesuai dengan keadaan yang sebenarnya!

\begin{tabular}{|c|c|c|c|c|c|c|}
\hline \multirow{2}{*}{ No } & \multirow{2}{*}{ Pernyataan } & \multicolumn{5}{|c|}{ Kategori jawaban } \\
\hline & & SS & ST & $\mathrm{R}$ & TS & STS \\
\hline 1 & $\begin{array}{l}\text { Disiplin sekolah hakikatnya adalah segala tata tertib yang } \\
\text { berkaitan dengan tanggung jawab siswa selaku warga } \\
\text { sekolah }\end{array}$ & & & & & \\
\hline 2 & $\begin{array}{l}\text { Disiplin sekolah lebih banyak mengekang perilaku siswa } \\
\text { dari pada menumbuhkan rasa tanggung jawab }\end{array}$ & & & & & \\
\hline & $\begin{array}{l}\text { Saya mendukung pemberlakuan seragam sekolah agar } \\
\text { tidak terjadi persaingan dalam berpakaian }\end{array}$ & & & & & \\
\hline $\int$ & $\begin{array}{l}\text { Saya kurang mendukung pemberlakuan seragam sekolah } \\
\text { karena banyak waktu terbuang hanya untuk menertibkan } \\
\text { seragam dari pada dipakai untuk belajar }\end{array}$ & & & & & \\
\hline 29 & $\begin{array}{l}\text { Seharusnya saya berangkat sekolah lebih awal agar } \\
\text { masih cukup waktu untuk mempersiapkan pelajaran }\end{array}$ & & & & & \\
\hline 30 & $\begin{array}{l}\text { Kehadiran saya di sekolah tidak harus lebih awal karena } \\
\text { guru yang mengajar tidak mewajibkan hadir lebih awal }\end{array}$ & & & & & \\
\hline
\end{tabular}

\section{Uji Coba Instrumen}

Melakukan uji coba instrumen merupakan langkah yang penting, apabila kita ingin mendapatkan hasil pengukuran yang dapat dipercaya. Tujuannya untuk menguji kesahihan pernyataan dan mengetahui derajat keterandalan instrumen. Di samping itu penyelenggaraan uji coba dimaksudkan untuk memastikan apakah pernyataan dan petunjuk pengerjaaan yang dirumuskan dapat dipahami dengan mudah oleh responden. Manfaat lain yang dapat dipetik ialah kita secara nyata dapat menentukan lamanya waktu yang dibutuhkan untuk menjawab seluruh pernyataan. 
Uji coba instrumen dilaksanakan pada kelompok subyek yang memiliki karakteristik yang mirip dengan kelompok subyek yang benar-benar akan diukur sikapnya. Idealnya diperlukan subyek sebanyak 10 kali dari jumlah item yang ada. Namun harapan ini sering kali tidak terpenuhi karena beberapa alasan. Memang belum ada ahli yang menyatakan secara tegas, berapakah sebaiknya subyek yang diperlukan untuk uji coba instrumen ini. Sebagai patokan, sebaiknya sampel uji coba tidak boleh kurang dari 30 orang.

\section{Menentukan Skor}

Langkah berikutnya adalah menentukan skor setiap pernyataan skala sikap. Menurut Azwar (2011: 138), penentuan skor setiap pernyataan skala sikap dilakukan dengan metode rating yang dijumlahkan. Metode rating yang dijumlahkan sering dinamakan penskalaan model Likert. Metode ini merupakan penskalaan pernyataan sikap yang menggunakan distribusi respon sebagai dasar penentu nilai skalanya. Dalam pendekatan ini tidak perlu adanya kelompok panel penilai, dikarenakan nilai skala setiap pernyataan tidak akan ditentukan oleh derajat favorabelnya masing-masing akan tetapi ditentukan oleh distribusi respon setuju atau tidak setuju dari sekelompok uji coba.

Untuk melakukan penskalaan dengan metode ini, sejumlah pernyataan sikap telah ditulis berdasarkan kaidah penulisan pernyataan dan didasarkan pada rancangan skala yang telah ditetapkan. Responden diminta untuk menyatakan kesetujuan atau ketidak setujuannya terhadap isi pernyataan dalam lima macam kategori jawaban, yaitu sangat tidak setuju (STS), tidak setuju (TS), entahlah (E), setuju (S) dan sangat setuju atau SS (Azwar, 2011: 140).

Ada dua cara untuk menentukan skala menurut Azwar (2011: 141), yaitu dengan cara menentukan skala deviasi normal dan menentukan nilai skala dengan cara sederhana.

1) Menentukan Skala dengan Deviasi Normal

Azwar (2011: 141) menjelaskan tentang cara menentukan skala dengan deviasi normal. Tujuan penentuan nilai skala dengan deviasi normal adalah untuk member bobot tertinggi bagi kategori jawaban yang paling favorable dan memberikan bobot rendah bagi kategori jawaban yang tidak favorabel. Jawaban favorabel adalah respons setuju terhadap pernyataan yang favorabel dan respon tidak setuju terhadap pernyataan yang tak-favorabel.Jawaban tidak favorabel adalah respons tidak setuju terhadap pernyataan yang tak-favorabel.

Dari jawaban responden terhadap setiap pernyataan akan diperoleh distribusi frekuensi responden bagi setiap kategori, yang kemudian secara komulatif akan dilihat deviasinya menurut deviasi normal. Dari sinilah nilai skala dapat ditentukan. Nilai skala ini kemudian akan menjadi skor terhadap jawaban individual responden yang diukur sikapnya.

2) Menentukan Nilai Skala dengan Cara Sederhana

Selain menentukan nilai skala dengan deviasi normal, menentukan nilai skala dapat juga dilakukan dengan cara sederhana. Penentuan skor skala dengan memberikan bobot dalam satuan deviasi normal bagi setiap kategori jawaban merupakan cara yang cermat dan akan menghasilkan interval yang tepat dalam meletakan masing-masing kategori pada suatu kontinum psikologis. Adanya fasilitas komputer sangat memudahkan prosedur analisisnya. Walaupun cara itu memerlukan waktu dan tenaga yang banyak, setiap penyusun skala sikap hendaklah berusaha melakukannya.

Apabila skala sikap yang disusun tidak untuk digunakan sebagai instrumen pengukuran yang menyangkut pengambilan keputusan yang penting sekali, seperti pada penelitian pendahuluan atau studi kelompok secara kecil-kecilan, kadang-kadang demi kepraktisan penyusunan skala sikap dapat menempuh cara sederhana untuk menentukan skor skala sikap yang ditulisnya. Dengan cara sederhana, untuk suatu pernyataan yang bersifat favorabel jawaban STS diberi 0, jawaban TS diberi skor 1, jawaban RR diberi skor 2, jawaban ST diberi skor 3, dan jawaban SS diberi skor 4. Untuk pernyataan yang tak-favorabel, respons STS diberi 4, jawaban TS diberi skor 3, jawaban RR diberi skor 2, jawaban ST diberi skor 1, dan jawaban SS diberi skor 0.

Penentuan skor item harus memperhatikan sifat pernyataannya. Untuk penyataan positif, jawaban "sangat setuju" harus diberi bobot paling besar. Sebaliknya jawaban "sangat setuju" untuk pernyataan negatif harus diberi bobot paling kecil. Untuk keperluan ini dipergunakan cara penentu nilai skala deviasi normal.

Dari jawaban subyek terhadap setiap pernyataan akan diperoleh distribusi frekuensi respon bagi setiap kategori jawaban, yang kemudian secara komulatif akan dilihat deviasinya menurut distribusi normal. Dari sinilah nilai skala dapat ditentukan. Selanjutnya nilai skala ini akan merupakan bobot atau skor terhadap jawaban subyek secara individual. 
Sebagai contoh, untuk pernyataan "peraturan tata tertib sekolah lebih banyak mengekang tingkah laku siswa dari pada menumbuhkan rasa tanggung jawab". Diperoleh distribusi frekuensi jawaban subyek sebagai berikut: "sangat setuju" $(\mathrm{SS})=36$ orang, "setuju" (ST) $=40$ orang, "ragu-ragu" $(\mathrm{RR})=64$ orang, "tidak setuju" (TS) $=44$ orang dan sangat tidak setuju (STS) $=16$ orang. Perlu diingat bahwa contoh pernyataan tadi termasuk jenis pernyataan negatif. Dengan demikian jawaban "sangat setuju" harus diberi bobot paling kecil.

Langkah-langkah perhitungan nilai skalanya dapat diringkas dalam tabel 1.

Tabel 2. Proporsi Jawaban Subyek Untuk Pernyataan Negatif

\begin{tabular}{lccccc}
\hline & \multicolumn{5}{c}{ Kategori Jawaban } \\
\cline { 2 - 6 } & \multicolumn{1}{c}{ SS } & \multicolumn{1}{c}{ ST } & RR & TS & STS \\
\hline F & 36 & 40 & 64 & 44 & 16 \\
f/N=p & 0.180 & 0.200 & 0.320 & 0.220 & 0.080 \\
Pk & 0.180 & 0.380 & 0.700 & 0.920 & 1.000 \\
Titik tengah pk & 0.090 & 0.280 & 0.540 & 0.810 & 0.960 \\
z & -1.341 & 0.583 & 0.100 & 0.878 & 1.751 \\
z+ 1,341 & 0.000 & 0.758 & 1.441 & 2.219 & 3.092 \\
\hline Pembulatan z & 0 & 1 & 1 & 2 & 3 \\
\hline
\end{tabular}

Baris pertama pada table 1 memuat frekuensi jawaban dalam setiap kategori. Keseluruhan frekuensi itu kalau dijumlahkan adalah sama dengan jumlah subyek yang menjawab pernyataan itu, yakni 200 orang $(\mathrm{N}=200)$. Proporsi (p) jawaban untuk masing-masing kategori diperoleh dengan membagi frekuensi dengan jumlah subyek. Misalnya, proporsi jawaban SS adalah 36/200 =0,180.

Baris ketiga (pk) adalah proporsi kumulatif, yang didapat dengan cara menambahkan proporsiproporsi disebelah kirinya. Sebagai contoh, proporsi kategori ST adalah 0,200 $+0,180=0,380$; proporsi kategori $\mathrm{RR}=0,320+0,200+0,180=0,700$, demikian seterusnya.

Titik tengah proporsi kumulatif dihitung dengan menggunakan cara berikut.

- Titik tengah $\mathrm{pk}=1 / 2 \mathrm{p}+\mathrm{pkb}$

- Dalam mana:

- $\mathrm{P}=$ proporsi dalam kategori itu

- $\quad \mathrm{Pkpb}=$ proporsi kumulatif dalam kategori disebelah kirinya

Sebagai contoh, titik tengah pk untuk kategori $\mathrm{RR}=1 / 2 \mathrm{X} 0,320+0,380=0,540$

Nilai $\mathrm{z}$ diperoleh dengan melihat harga $\mathrm{z}$ untuk masing-masing titik tengah pk dalam table deviasi normal. Tabel ini terdapat dalam buku-buku statistic yang standar. Selanjutnya harga z negative yang diperoleh diubah menjadi positif. Caranya ialah dengan menambahkan harga sebesar $\mathrm{z}$ pada kategori paling kiri terhadap semua z pada kategori paling kiri (SS) adalah-1,341. Agar harganya menjadi positif, harga $\mathrm{z}$ pada SS ditambah dengan 1,341. Jadi, $-1,341+1,341=0,000$. Kemudian untuk harga $\mathrm{z}$ kategori $\mathrm{ST}=0,583+1,341=0,758$; sedangkan untuk kategori $\mathrm{RR}=0,100+1,341=1,441$, demikian baris terakhir dalam table 1 . Adalah pembulatan dari harga $\mathrm{z}$ pada baris sebelumnya. Pembulatan dilakukan dengan memperhatikan angka yang terletak dibelakang koma. Jika angka dibelakang koma sama dengan atau lebih besar dari 0,500, maka angka yang berada persis di depan koma ditambah satu. Apabila angka dibelakang koma lebih kecil dari 0,500 dihilangkan saja.

Prosedur yang sama juga diterapkan untuk menentukan skor pernyataan positif, dengan catatan kategori jawaban "sangat tidak setuju" (STS) ditempatkan pada kolom paling kiri dalam table analisis.

Dari contoh di atas tampak bahwa deretan angka yang dihasilkan dari pembulatan harga deviasi $\mathrm{z}$ untuk masing-masing kategori, tidak memiliki interval yang sama. Sesungguhnya angka-angka yang dihasilkan itulah yang dijadikan nilai skala atau skor bagi setiap kategori jawaban. Ini adalah cara yang cermat untuk menentukan nilai sikap, karena interval skor yang dihasilkan sesuai dengan keadaan subyek yang menjawab instrument tersebut. Akan tetapi cara yang diuraikan di atas memerlukan banyak 
waktu dan tenaga, apalagi kalau subyek yang dijadikan sample lebih lama, setelah skala itu benar-benar diterangkan pada subyek yang sesungguhnya.

Untuk mengatasi hal tersebut penentuan skor untuk masing-masing kategori jawaban dapat dilakukan dengan cara yang sederhana. Dalam hubungan ini pertama-tama harus ditetapkan terlebih dahulu mana pernyataan positif mana pernyataan negatif. Untuk pernyataan positif, katergori jawaban SS diberi skor 4, ST diberi skor 3, RR diberi skor 2,TS diberi skor 1dan STS diberi skor 0. Sedangkan untuk pernyataan negatif, jawaban SS diberi skor 0, ST diberi skor 1, RR diberi skor 2, TS diberi skor 3 dan STS diberi skor 4.

Menurut Likert, seperti yang dilaporkan oleh Allen Edwards, pemberian skor yang didasarkan atas deviasi normal menunjukan korelasi yang tinggi $(r=0,99)$ dengan pemberian skor dengan cara sederhana. Atas dasar inilah maka dalam praktek orang jarang menggunakan cara penentuan skor kategori jawaban atas dasar deviasi normal.

\section{Melakukan analisis item untuk mengetahui keterandalan dan kesahihan instrumen}

Dalam bidang psikologi pendidikan, keterandalan (reliabilitas) instrumen sering diartikan sebagai keajegan (consistency) dari instrumen tersebut. Ini berarti suatu instrumen dikatakan memiliki keterandalan sempurna, manakala hasil pengukuran berkali -kali terhadap subyek yang sama selalu menujukan hasil atau skor yang sama. Praktiknya kita hampir tidak pernah mendapatkan instrumen yang memiliki keterandalan sempurna. Skor yang kita peroleh dari pengukuran terhadap seorang subyek secara berulang-ulang dengan alat yang sama, pada umumnya berbeda besarnya. Ini berarti bahwa dalam hasil pengukuran riil yang diperoleh seseorang pada satu kali pengukuran bukan merupakan skor sebenarnya, melainkan merupakan skor sebenarnya ditambah dengan kesalahan.

Uji reabilitas dimaksudkan untuk menjamin ketepatan atau keajegan instrumen yang digunakan merupakan sebuah instrumen yang handal, konsisten, dan stabil, sehingga bila digunakan berkali-kali akan menghasilkan data yang sama. Pengukuran tingkat reliabilitas alat pengukur data dalam penelitian ini dengan menggunakan Alpha Croncbrach. Besarnya koefisien Alpha merupakan tolak ukur dari tingkat reliabilitasnya. Tahap uji validitas dan reliabilitas ini dilakukan dengan menggunakan program SPSS 18.0 for windows atau versi yang lebih baru. Reliabilitas alat penilaian adalah ketepatan atau keajegan alat tersebut dalam menilai apa yang dinilainya, artinya, kapan pun penilaian tersebut digunakan akan memberikan hasil yang relatif sama (Sudjana, 2008: 16). Dapat diartikan sejauh mana instrumen dapat diandalkan, Uji reliabilitas penelitian adalah dengan menggunakan teknik Alpha yang dikembangkan oleh George dan Mallery (2010) untuk menentukan tingkat reliabilitas instrumen menggunakan kriteria sebagai berikut :

$$
\begin{aligned}
& \alpha \leq 0,7 \quad \text { : tidak dapat diterima } \\
& 0,7<\alpha \leq 0,8: \text { dapat diterima } \\
& 0,8<\alpha \leq 0,9: \text { reliabilitas bagus } \\
& \alpha>0,9 \quad: \text { reliabilitas memuaskan }
\end{aligned}
$$

Berkaitan dengan uji validitas skala sikap, dilakukan untuk mengetahui kesasihan sebuah instrumen pengukuran. Artinya apakah instrumen tersebut mampu mengukur apa yang seharusnya diukur. Item skala sikap dianggap valid apabila mencapai nilai koefisien korelasi setiap skor dengan skor totanya lebih besar dari 0,30, sedangkan apabila koefisien korelasi kurang dari 0,30 maka item tersebut dianggap tidak valid atau harus dihilangkan (Azwar, 2011: 158). Oleh karena itu penelitian ini menggunakan batas minimal koefisien korelasi 0,30. Jika menggunakan SPSS, angka yang digunakan untuk melihat tingkat validitas instrumen skala sikap adalah koefisien corrected item-Total correlation. Apabila hasil komputasi menggunakan SPSS menunjukkan angka koefisien corrected item-Total correlation $\geq 0,30$, maka item skala sikap tersebut dikatakan valid.

Langkah-langkah menggunakan SPSS dalam melakukan uji reliabilitas dan validitas item skala sikap adalah sebagai berikut. Pertama, klik Analyze -> Scale -> Reliability Analysis, maka akan nampak menu seperti pada gambar 2 berikut. Selanjutnya masukkan seluruh variabel ke kolom items seperti pada gambar 3 . 
Rambu-rambu Penyusunan Skala Sikap Model Likert untuk Mengukur Sikap Siswa

(Mawardi)

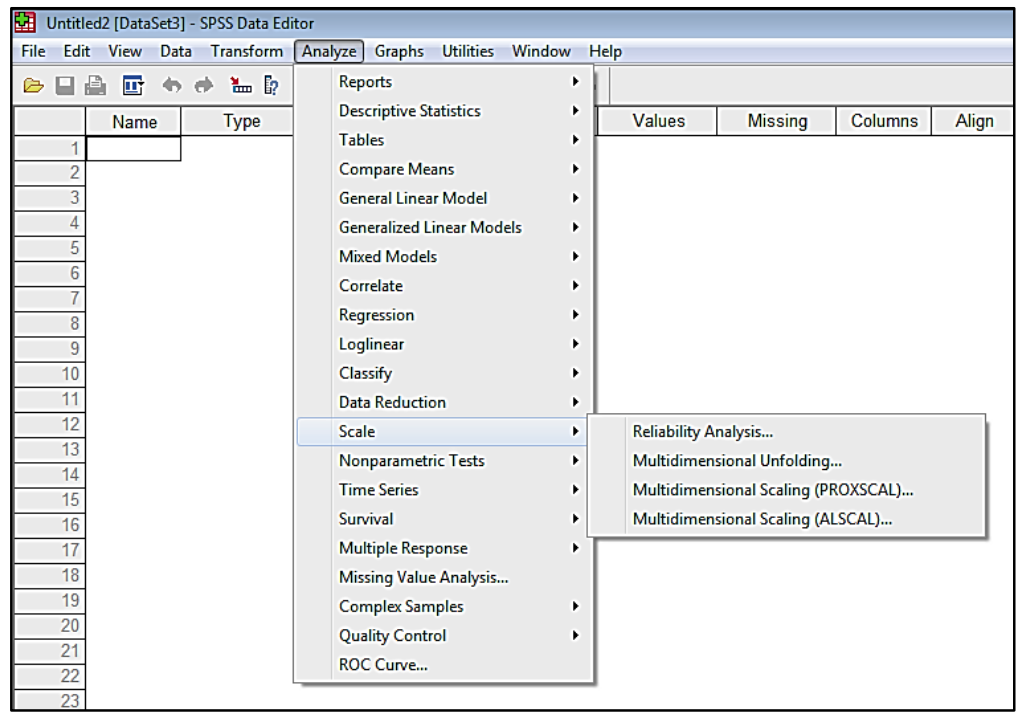

Gambar 2. Langkah pertama uji reliablitas dan validitas instrumen

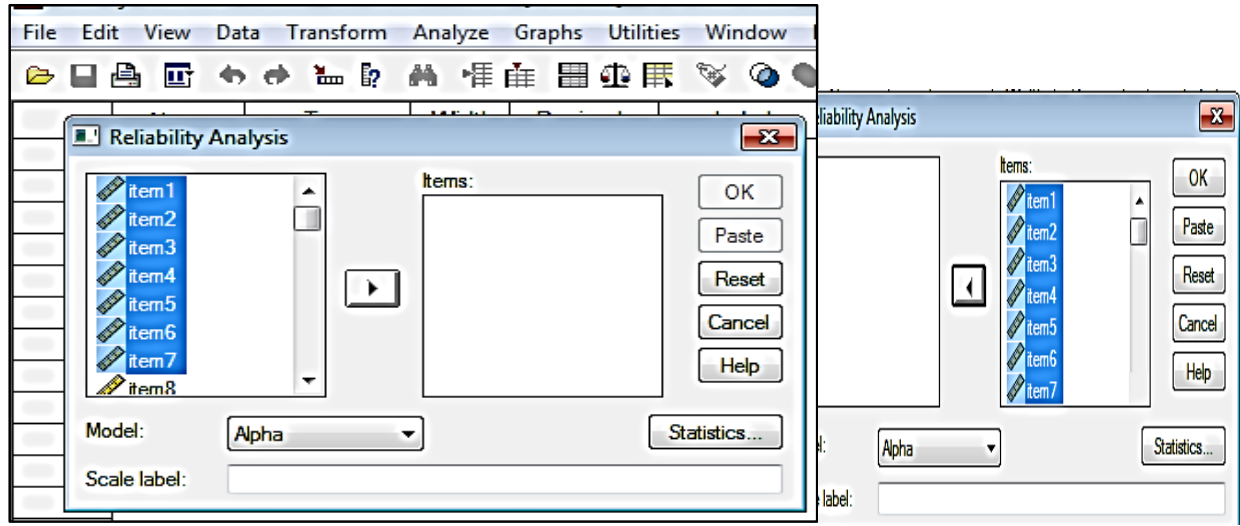

Gambar 3. Langkah kedua uji reliablitas dan validitas instrumen

Langkah terakhir klik OK, maka akan keluat output seperti pada gambar 4.Nampak bahwa contoh uji reliabilitas Alpha menunjukan angka 0,805. Artinya angka koefisien Alpha tersebut dapat diteruima, sehingga instrumen dapat digunakan untuk mengukur sikap siswa.

\section{Reliability}

[DataSet2] E: \DISERTASI MAWARDIDDATA SPSS\Data uji reliabilitas ANGKET IMPLEMENTASI.sav

Scale: ALL VARIABLES

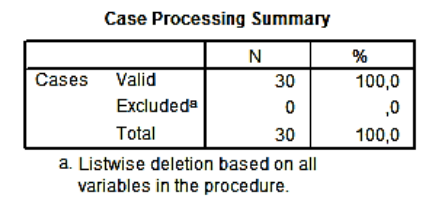

\begin{tabular}{|c|c|}
\hline \multicolumn{2}{|c|}{ Reliability Statistics } \\
\begin{tabular}{|c|r|}
\hline $\begin{array}{c}\text { Cronbach's } \\
\text { Alpha }\end{array}$ & N of Items \\
\hline, 805 & 35 \\
\hline
\end{tabular} \\
\hline
\end{tabular}

Gambar 4. Langkah terakhir, uji reliablitas dan validitas instrumen 
Selanjutnya untuk menguji validitas item skala sikap klik statistic, kemudian berturut-turut centang item, Scale dan Scale if item deleted, seperti pada gambar 4, kemudian tekan Continue, maka akan muncul output koefisien corrected item-Total correlation seperti gambar 5.

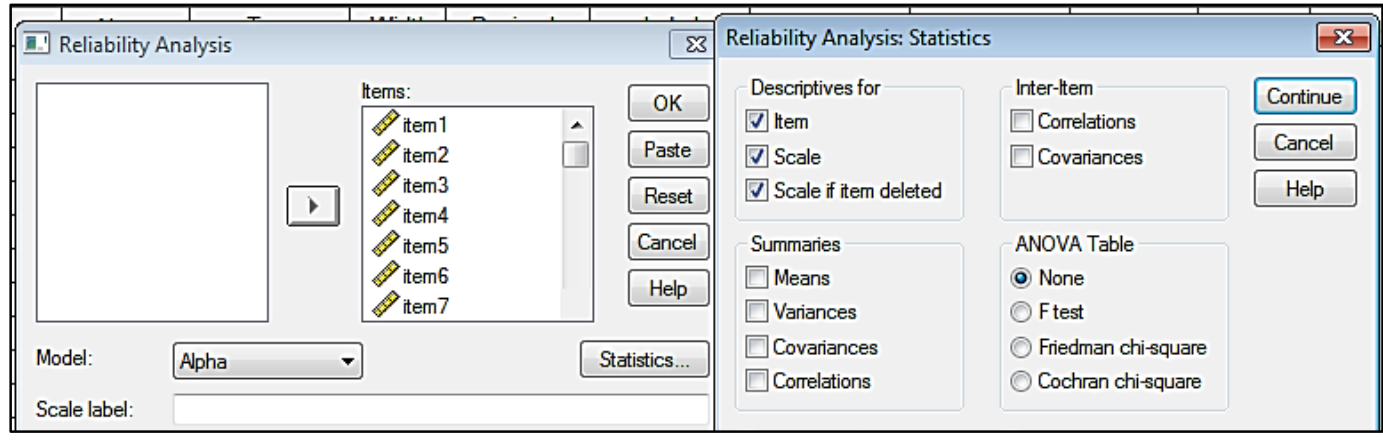

Gambar 5. Langkah uji validitas item

\section{Item-Total Statistics}

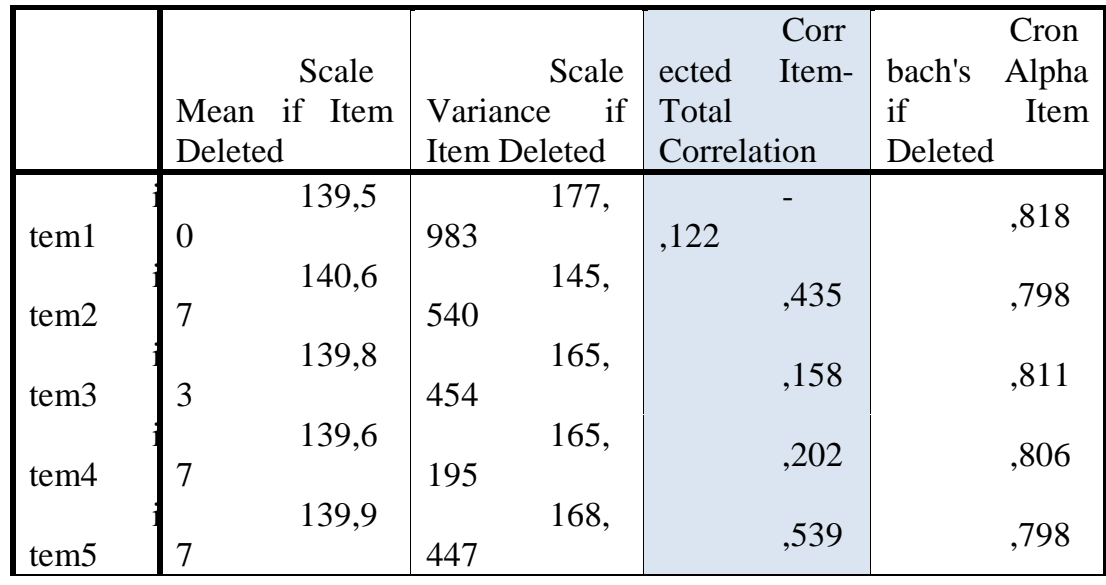

\section{Gambar 6. Output uji validitas item}

Dari gambar 5 nampak bahwa contoh penggalan output SPSS menunjukkan angka koefisien corrected item-Total correlation bertutrut-turut sebesar item $1=-0,122$; item $2=0$, 435; item $3=0$, 158; item $4=0,202$; dan item $5=0,539$. Apabila hasil komputasi menggunakan SPSS tersebut di atas dibandingkan dengan kriteria angka koefisien corrected item-Total correlation $\geq 0,30$, maka item skala sikap nomor 2 dan 5 yang valid, sedangkan item nomor 1, 3 dan 4 tidak valid, sehingga perlu diperbaiki rumusannya.

\section{PENUTUP}

Sebagai catatan penutup dari tulisan ini, ada dua hal penting yang perlu kita jadikan sebagai dasar dalam menyusun instrumen penilaian ranah sikap. Pertama, bahwa instrumen penilaian ranah sikap dalam buku guru dan buku siswa yang disediakan oleh pemerintah beriringan dengan pemberlakuan kurikulum 2013 harus dicermati sungguh-sungguh, apakah sudah sesuai dengan kaidah pengukuran sikap yang sebenarnya. Jika hasil analisis menemukan bahwa instrumen tersebut belum mengarah pada instrumen pengukuran sikap yang benar, guru wajib menyusun instrumen yang baru yang sesuai. Bahkan Setiadi (2016: 116) secara khusus menyarankan perlunya pelatihan bagi guru untuk memnyusun instrumen penilaian sikap. Kedua, Kemendikbud memberikan ruang kepada para guru untuk melakukan analisis buku-buku tersebut.Artinya penggunaan buku Guru dan buku siswa tidak bersifat mutlak. Maknanya bahwa ada kesadaran dari guru perlu ada upaya untuk melakukan pengembangan lebih lanjut. Dalam kaitan dengan saran terhadap Kemendikbud ini, Setiadi, H. (2016). 
Rambu-rambu Penyusunan Skala Sikap Model Likert untuk Mengukur Sikap Siswa

(Mawardi)

\section{DAFTAR PUTAKA}

Azwar, Saifuddin. 2011. Reliabilitas dan Validitas. Yogyakarta: Pustaka Pelajar

Azwar, Saifuddin. 2011. Sikap Manusia, Teori dan Pengukurannya. Yogyakarta: Pustaka Pelajar

Dhinata, S. C. (2016). Analisis Kesesuaian Buku Guru Dan Buku Siswa Kelas I SD/MI Tema Keluargaku Dengan Kurikulum 2013 (Doctoral dissertation, Universitas Negeri Semarang). Tersedia di: https://lib.unnes.ac.id/28194/1/1401412554.pdf

George, D. \& Mallery, P. 2010. SPSS for Windows step by step: A Simpel Guide and Reference 18.0 Update. Boston: Allyn and Bacon.

Henerson, M.E., Lynn Lyons Morris, L.L., Gibbon, C.T.F. (1987). How to measure attitud. Newbury Park, California : Sage Publications, the International Professional Publishers.

Kusaeri, K., \& Cahyan, E. D. H. (2016). Sikap, Harapan dan Persepsi Siswa pada Matematika serta Implikasinya terhadap Kemampuan Regulasi Diri. Jurnal Pengajaran MIPA, 21(2), 114-121.

Kusaeri, K. (2019). Penilaian Sikap Dalam Pembelajaran Matematika. JPM: Jurnal Pendidikan Matematika, 5(2), 61-70.

Mawardi, M., Wardani, N. S., Hardini, A. T. A., \& Kristin, F. (2019). Model Desain Pembelajaran Tematik Terpadu Kontekstual Untuk Meningkatkan Kebermaknaan Belajar Siswa SD. Scholaria: Jurnal Pendidikan dan Kebudayaan, 9(1), 48-61.

Mar'at. (2006). Sikap Manusia: Perubahan serta Pengukurannya. Bandung : Ghalia Indonesia

Sari, F. R. (2017). Analisis Kesesuaian Buku Guru Dan Buku Siswa Kelas IV SD/MI Tema Selalu Berhemat Energi Dengan Kurikulum 2013 (Doctoral dissertation, Universitas Negeri Semarang). Tersedia di: https://lib.unnes.ac.id/31522/1/1401413560.pdf

Setiadi, H. (2016). Pelaksanaan penilaian pada Kurikulum 2013. Jurnal Penelitian dan Evaluasi Pendidikan, 20(2), 166-178.

Sudjana, Nana. (2008). Dasar-dasar Proses Belajar Mengajar. Bandung: Sinar Baru Algensindo.

Wijaya, A (2014). Pentingnya analisis buku guru dan buku siswa dalam implementasi Kurikulum 2013. Yogyakarta: P4TK.

Zakaria, R. T. (2011). Penilaian Sikap. Jakarta: Pusat Penilaian Pendidikan Balitbang Kementerian Pendidikan dan Kebudayaan RI 